\title{
Artifacts and The Problem of Ethical Extensionism - Selected Issues
}

Magdalena Holy-Luczaj

University of Information Technology

and Management in Rzeszow,

Poland

e-mail: mholy@wsiz.rzeszow.pl

\begin{abstract}
:
This paper addresses the problem of extending ethical obligations toward usable things. The first part reconstructs current debates on the metaphysical and ethical status of artifacts. Next, drawing upon Tadeusz Kotarbinski's reism, I describe artifacts as concretes, focusing on the possibility of their damage and destruction. The core part of the article analyzes ethical implications of the following issues: 1) using artifacts, 2) their production, 3) purchase and sale of artifacts, and 4) the post-use period.

Keywords: ethical extensionism, artifacts, postnatural extensionism, environmental philosophy, philosophy of technology.
\end{abstract}

\section{Introduction}

The debate about expanding ethical obligations of human beings toward nonhumans has been going on for several decades. Arguments for including different animal species, plants, other living organisms, and finally inanimate entities in the boundaries of ethics have successively appeared in numerous works dealing with this issue. Now - as I attempt to show - it is worth establishing possible grounds for extending human moral obligations toward artifacts as beings which status can be improved or deteriorated through human activity.

Usable things, on which this paper concentrates, belong to a subset of technical artifacts. It consists of single objects created by humans, which have a determined material identity and serve established functions. Hence, from this classification are excluded electronic/digital beings (such as a computer software), since they are not associated with particular, physical carriers.

The above specification is necessary to focus on problems, which are situated at the intersection of environmental philosophy and philosophy of technology, such as production and use of usable things, or managing them after utility period. I shall present them in the context of regarding usable things as moral patients.

\section{Emancipation of Artifacts}

Philosophy for centuries, actually from its very beginnings, disregarded technical artifacts [46, pp. 1-2], [2, pp. 99-100], [34, pp. 9-10]. It was not until the last few decades when interest in them 
increased significantly. It can be observed both in the tradition of analytic and continental philosophy, as well as in the currents trying to cross this divide.

\subsection{Analytic Philosophy}

Studies on artifacts diverged in analytic philosophy as a part of its reflection on technology [46, p. 4] in order to do justice to artifacts as fully-fledged beings [15, p. 3], [2, p. 100]. Ontological emancipation of artifacts is usually justified using one of two strategies. On the one hand, scholars attempt to describe artifacts as generally identical with natural beings, presenting differences between them as secondary for their identity [3, p. 60]. On the other hand, artifacts are portrayed as completely different from natural beings, which, however, does not mean that they are of inferior status [16, pp. 123-124], [47, p. 11]. Many philosophers argue here with Aristotle [16, p. 124], [3, p. 50], [47, pp.7-8], [46, p. 29], who did not consider artifacts (beings which are produced) to be genuine substances, even though they are particular individuals (there is a significant difference in this regard between his Categories and Metaphysics [22, p. 13], [2, pp. 104-105]). According to him, artifacts are flawed ontologically, because, in contrast to natural beings, they do not have the principle of origin in themselves, but this principle is located in man as their creator.

In analytic philosophy, there are basically two main determinants of the identity of artifacts. The first one is their non-naturalness [15, p. 123]. Yet, currently, many philosophers highlight the problematic division of beings to the natural and artificial in the context of the development of science and technology and their interconnections [3, p. 64], [6]. Moreover, it is argued that if human beings are natural entities, their products are natural as well [see 3, p. 65]. The second one is that artifacts are functional objects [15, p. 123]. This characteristic is often even identified with the essence of the artifact. As Houkes and Vermaas point out a large number of artifacts is named in functional terms, such as 'screwdriver' [15, p. 124]. However, recently there is more and more visible tendency toward examining artifacts not by their functions, but by the way they are produced and used [14, p. 52]. Therefore, the current definition of artifacts is well framed in the expression "produced-to-use". It means that technical artifact is the material object with a certain function and a use plan, which was designed and constructed by human agents. It is of particular importance that this definition highlights that the agent, who constructs the artifact is not a single person who produces relatively simple artifacts, starting with a (perhaps personal) desire and ending with a finished product ("the artisan"), but this is a team of designers, engineers and producers [16, pp. 403-404].

One can obviously and reasonably recognize that the question of whether the artifact is produced by an artisan or whether it is the product of engineering process does not make any difference to the nature of the artifact (what counts is how and whether the artifact is actually used) and as such it is insignificant [16, p. 414]. Yet, it gains considerable importance in the context of the morality artifacts as opposed to the thesis of their neutrality. According to the latter, artifacts are not value-laden, but at most they constitute means or requisites used in activities that can be assessed in ethical terms. For this reason - some scholars hold - we cannot acknowledge that the work of designers and engineers may be subject to ethical evaluation [47, p. 16], [34, pp. 71-109]. Critics of this belief, however, indicate that some of the artifacts to a greater extent than other things can do harm to people and the environment, so they cannot be regarded as ethically neutral entities. In such a case production of these artifacts must be assessed in ethical categories. The main question is how engineers and designers can change the world for better or worse by creating specific artifacts [16, p. 417].

There is also another standpoint, according to which an artifact itself is a moral agent. In such a perspective artifacts are no longer merely passive instruments used for good or bad purposes, but they are seen as something that actively shapes human existence [34, pp. 123-137]. It is due to the fact that some decisions and activities are delegated to devices, an example of which can be speed control device in cars [46, p. 213]. However, there were numerous allegations against this concept, e.g. establishing technocracy, which could lead to totalitarianism. A second objection to 
assigning morality to things concerns the fact that artifacts are not able to make deliberate decisions about their influences on human action. Things lack intentions, runs this objection, and thus cannot be held accountable for their behaviors [46, pp. 213-214]. Some scholars, however, believe that things carry morality because they shape the way people experience their world and organize their existence, regardless of whether this is done consciously and intentionally or not. Accordingly, the ethics of artifacts in analytic philosophy is understood as research on moral agency of artifacts. The possibility to recognize artifacts as moral patients is neglected or treated inexplicably as secondary (as David Gunkel shows with respect to robots [12, pp. 119-124]). The notion of moral considerability refers in this case to the fact that production of artifacts requires taking into consideration various factors [13, p. 227].

\subsection{Continental Philosophy}

Continental philosophy examines the issue of artifacts assuming that human beings and things are essentially different, which, however, by no means negates their bonds [see 46, p. 19]. The leading role is played by the interpretation and critique of the philosophy of Martin Heidegger. Some researchers analyze the early period of it, which belongs to the existential paradigm and concentrates on the human understanding of ways of being. Heidegger contended that the most intuitive is the one which can be grasped in the attitude which humans have toward tools, that is beings which are situated in the context of their functions and mutual belonging [7, p. 111]. On the other hand, numerous studies are devoted to the later philosophy of Heidegger, which is a project of "another thinking" that attempts to go beyond anthropocentrism. It assumes that we should think of tools as things, which are the spots for "enowning" - happening of being. According to Heidegger, things disclose themselves in their particularity. However, it is hard to notice this in the optics of modern technology, in which they are merely elements of "the resource" [see 5].

Ethical issues related to artifacts in continental philosophy are under the great influence of Heidegger's thought as well, which is linked with concepts inherited from other important thinkers belonging to this tradition, such as the idea of otherness (the Other) brought by Emanuel Levinas [5], [21]. In result, the most significant categories of continental ethics of things (which can be seen as a consideration of the human relations with things) are respect for being and otherness, as well as care recognized as an existential phenomenon.

Continental tradition, however, is also developed in the more pragmatic direction. An example of this approach is postphenomenology of Don Ihde, widely regarded as one of the leading philosophers of technology. Although Ihde complains that Heidegger's concepts are technophobic and entangled in romantic cliché which idealize premodern reality, he thinks that it is worth to draw upon Heidegger's idea of worldliness as something toward which human beings orient their cognition, intentionality as the basic structure of our cognition, and technology as the filter, which modifies perception of a reality [see 20, pp. 103-15]. Ihde in his research concentrates on artifacts understood as objects, which mediate human knowledge and action, and understands this mediation as a form of activity of things, which can be subject to ethical evaluation [19].

\subsection{Posthumanism}

Another interesting trend is a pursuit to bring together continental philosophy with the perspective of science and technology studies. Scholars employ here the concept of actants, that is nonhuman actors, created by Bruno Latour [see 21]. According to Latour, we cannot understand reality if we downplay the role of nonhuman beings in lives of human beings because we cannot separate these two groups - they are intrinsically linked in the network of mutual relations. Furthermore, belonging to this network is the condition of gaining their proper identity and possibility to act. For this reason, Latour holds, we should not speak of human and nonhuman actors, but rather actants, which are natural beings (to include virtues, climate, species), technological infrastructure, various 
objects from our everyday surroundings, law, social institutions, as well as ideas and values [6, pp. 158-159].

The desire to treat humans and nonhumans "symmetrically" culminates in the posthumanism. Keeping in mind that this is an umbrella term for a wide variety of projects developed in the last three decades [see 6, pp. 154-155], it can be concluded that one of the key postulates of posthumanism says that attitude reserved hitherto exclusively for humans (respect, attention to the preservation of welfare, avoiding harms) should be extended to all beings in the widely understood environment (which constitute natural animate and inanimate beings as well as artificial beings) and not only homo sapiens [8, p. 31].

Posthumanists highlight indivisibility of metaphysical universe, in which all actors/actants interact with each other, what means that also things affect humans. Posthuman theorists argue that taking away agency from nonhuman beings supported human hubris, which translated into an arrogant way of dealings with beings other than human [6, p. 155], [4, p. 12]. Accordingly, in posthumanism, the ground for taking artifacts into ethical consideration is primarily their moral agency.

\subsection{Postnatural Environmentalism}

The problem of moral patiency of artifacts is important for the postnatural environmentalism. This approach criticizes traditional environmentalism for excluding built environment, humanized landscape and artifacts from the scope of its interest and being focused solely on natural beings [50, pp. 2, 88], [48], [49], [44]. In its pursuit to expand the reach of moral considerability beyond traditional limitation to humans (traditional) environmental philosophers include nature to it, but they do not worry about things which environ us on a daily basis: buildings and useful things [50, pp. 2, 88]. Such attitude toward artifacts has, as postnatural environmentalists show, negative effects. First, it brings a sense of alienation in human beings, because it assumes that their creations are different from natural ones and thus they do not deserve moral attention. Second, it results in the thoughtless and irresponsible way of dealings with artifacts. Postnatural environmentalists want to change it by enhancing the metaphysical and ethical status of artifacts.

It is of crucial importance to emphasize that postulate to include artifacts into ethics does not intend to devaluate natural entities nor to ground normative anthropocentrism (subordinating functioning of the entire ecosystem solely to human needs). On the contrary, Steven Vogel suggests that we should rather stop unreflective exploitation which tries to satisfy only human needs [50, pp. $137,163]$. At the same time, he underlines that his analysis has an introductory and preliminary character in ascribing moral patiency to artifacts and requires further research [see 50, p. 164]. I do believe it is worth taking them. In what follows, I map the most important areas which should be explored.

\section{Moral Considerability, Patients and Agents}

Addressing the problem of ethical obligations toward usable things requires reconstructing conceptual framework and a detailed analysis of categories, which will be employed in such a project. The first one is moral considerability, which is a capacity to absorb moral consideration. That is to say, it is belonging to the class of individuals, which deserve moral consideration (assessing actions undertaken toward them in terms of ethics), even though such beings are not able to morally assess their own actions. This restriction is compatible with the distinction between moral patients and moral agents. Moral patients are beings to whom we consider that we owe moral obligations, and agents are those who are held to be morally responsible for their actions. What is of particular importance, all moral agents are moral patients, but not all moral patients are agents (as it is for example in the case of mentally impaired persons or little children) [10].

Many ecophilosophers refers to this division when they argue for shifting boundaries of ethics in order to include natural entities. Ethics of things can identify strategies, which they 
employed in extending ethics towards various kinds of natural beings and critically assess whether they can be modified and adopted in attempt to take artifacts into moral consideration

Furthermore, it would be indispensable to examine the problem of egalitarianism of ethical extensionism, answering the question whether an extension of ethical consideration necessarily means that the interests of all beings should be considered on an equal footing. I will present various scenarios regarding graduality and egalitarianism of moral considerability concerning different entities and the possible principles that one can follow in case of conflict of life interests (distinguishing them from the so-called secondary and tertiary needs [see 9, p. 15].

Another issue concerning ethical considerability, which should be explored, is the relationship between metaphysics and ethics. Theorists of moral consideration assume that assessment whether some being deserves it, depends on what is this being (that is to say, whether it has all necessary characteristics qualifying it to be considered ethically [see 13, pp. 28-39]). A close relationship between metaphysics and ethics was indicated directly both by environmental philosophy and posthumanism. Unfortunately, their representatives do not elucidate in more details the nature of this connection [see 27, p. 99], just like analytic philosophers quoted earlier. In my opinion, this connection can be explicated by referring to the concept of "idea" presented by Arthur Lovejoy, who recognized the idea as the disposition to think with the use of categories specific to the cultural context, which moves human imagination, behavior, and emotions. Following this path, it can be argued that metaphysics should not be treated as a logical justification of ethics, but metaphysical assumptions (metaphysical "ideas") can be considered as a component of the motivation of human behavior.

The key question is as follows: what metaphysical image of usable things can induce us to include them in the scope of ethical reflection? Certainly, there are many possible solutions. My suggestion is to present useful things in accordance with well-rooted in Polish philosophical tradition Tadeusz Kotarbinski's ontology as "concretes."

\section{Concretes}

Tadeusz Kotarbinski defined "concretes" in conformity with the common usage of the word "thing" as "objects located in time and in space and having certain physical characteristics" [30, p. 233]. Concretes, according to Kotarbinski, are humans beings, animals, plants and inanimate beings both natural and artificial [31]. In the course of the development of his metaphysical theory, Kotarbinski decided that the notion of "concretes" is identical with terms "body" and "thing", but it avoids difficulties related to those names - ("body" is usually used not in the sense of physics, but biology, where it is interchangeable with "organism" and is limited to livings beings, whereas "thing" is usually associated with inanimate entities, inorganic solids [see 32, p. 29]. In the context of the problem of the metaphysical status of usable things, it is important that Kotarbinski not only rejected dualism of animate and inanimate beings, but also resigned from strict separation of natural and non-natural beings - he listed a watch as an example of a concrete [31, p. 283].

Drawing upon Kotarbinski's theory it can be shown that usable things are as real as natural entities are and therefore the thesis that they do not actually exist is counterintuitive [2, p. 64], [24, p. 93]. Furthermore, concretism inclines us to see metaphysical universe rather nonhierarchically, what can support rejecting belief in ontological subordinance of artifacts [2, p. 60]

In the characteristics of usable things, a premium should be put, however, on the fact that they - as particular individuals - can be irreparably damaged and destroyed. Even if the usable thing remains a material object after the destruction, it no longer has its integral identity, or more precisely, it has no longer a possibility to fulfill it. It is this immanent feature of usable things that makes it necessary to separate them from the broader group of technical artifacts, which includes, for example, computer software, which has significantly different material status (most researchers ignore this fact [2, p. 49], [47, p. 5], [see 34, p. 38]. The difference between physical beings and electronic beings consists in that the latter, unlike physical beings, are perfectly multiplicable. For digital-beings, there is no distinction between originals and duplicates. As a result, a single digital- 
being literally can exist at multiple locations at the same time and can endure the test of time, as Joohan Kim underlines [28, p. 99]. Moreover, a digital-being is far less likely to be irreversibly destroyed.

It is worth highlighting that such a destruction of usable things can be caused by human activity. The possibility of irreversible destruction of a particular entity by human actions should move human ethical imagination and at the same time can define boundaries of moral considerability. Distinguishing between beings which can be hurt or benefit thanks to human activity and beings which can be damaged or repaired I find vague and hard to defend [1, pp. 3132], [18], [11].

Likewise, lack of ability to self-maintain and self-repair should not disqualify artifacts from the moral domain. Many environmental philosophers argue that a difference in the degree of complexity (as, for example, between people and animals) should not automatically eliminate certain beings from the ethical domain. Yet, it appears that for artifacts these environmental thinkers do not adhere to this rule. In this case, they even fall into the trap of recognizing something as "mere." This is a very dangerous pattern of thinking, because it gives us a kind of alibi. If something is seen as insignificant, we can deal arbitrarily with it. We can excuse ourselves from responsibility for such things - for "mere things" [18] - and this is one way environmental philosophy sees artifacts. For this reason, environmental philosophy does not do the right thing, when it grants us the right to be thoughtless about beings which constitute our everyday environment, even if they are less complex than other beings [see 50, p. 163].

Moreover, the identity of artifacts is not so poor as some environmental philosophers hold. Artifacts, from the moment they are produced, are autonomous in relation to human beings - they deteriorate, decay, refuse to work, and have unexpected applications. In short, human intention does not determine them completely [50, pp. 105, 113], [14, pp. 52-55], [3, p. 50], [46, p. 29].

It seems then that it not so absurd to challenge alleged obviousness of embargo on taking usable things into ethical consideration. Revisiting ontological status of usable things is of crucial importance for identifying the most serious dilemmas related to them, which we have to face. They can be dived into four groups, respectively linked with: using, producing, sale and purchase, afteruse period and threats.

\section{Using}

The problem of moral considerability of usable things requires us to examine in the first place activity, which most commonly leads to the destruction of the thing: using. It is using which contributes to deteriorating of the thing (loss of certain qualities) and eventually its destruction (that is the "using up" of a thing). Subsequent attempts to regenerate the thing only delay this effect.

Furthermore, using, as theories of intrinsic value assume, introduce oppression and hierarchy - an entity, which uses another entity, makes it subordinate and disavows its ontological status. Due to this intrinsic value is often identified with non-instrumental value [see 9, p. 14].

Such an approach is another reason, why artifacts are excluded from the scope of ethics by environmental philosophy. If they have only usable character (what is even reflected in their name), there is no rescue for them - they are doomed to be exploited and disregarded. Natural beings, on the other hand, have different scenarios of their existence, mainly undisturbed development.

Such a belief, however, suggests a peculiarly atomistic picture of the world, which undermines the attempt of environmental philosophy to convince people to recognize the interdependence of the different parts of the natural the world. This contradiction is highlighted by environmental philosophers who are skeptical about the identification of the inherent or intrinsic value with the non-instrumental value [39], [36]. Using can be seen as a kind of cooperation, in which entities disclose various aspect of their identity. In order to reject the strict opposition of the inherent and instrumental values, it will be necessary to develop the argument that if some entity is not used, this does not mean that it becomes meaningless or it does not have any longer a right to exist, but it refers to the inability to manifest and fulfill its identity. 
Revision of assessment of the phenomenon of use is crucial for our perception of artifacts their usable character does not longer undermine the ethical dimension of dealing with them. Hence, it would be essential to ask if it is possible to achieve a balance between enabling things to realize their potential and protecting them from decay. Answering this question is one of the most fundamental tasks of the ethics of things. The starting point should be distinguishing between "proper use" and "exploitation" as suggested by Heidegger in Anaximander's saying and What is Called Thinking?. We can expand on this concept by indicating when using the thing becomes improper and unacceptable from the perspective of its integral identity [see 14, pp. 52-54]. In this regard, it will also be important to distinguish between alternative and standard variants of the proper use [see 14, pp. 52-53].

\section{Production}

Except for already discussed issues, there is also one more which plays a significant role in excluding artifacts from the sphere of ethics by environmental philosophy - it is a fact of being produced by human beings. Just as Aristotle, so many environmental thinkers hold that the way some being occurs is decisive for its status and ontological autonomy [33, p. 49]. It can be argued whether more important is the way of creating or the final result of it, which in case of artifacts is concrete individuum [see 46, p. 29]. Yet, for our considerations, two problems would be the most important: being secondary to the material from which something has been produced and replaceability.

Many environmental philosophers highlight that artifacts, again unlike naturally-occurring beings, are secondary to the material, which they were made from [see 13, p. 50]. For example, a tree is not derivative of wood, while a wooden chair is. There are of course degrees of artefacticity in this regard. The material can be natural (e.g., wood), can be derived from natural material (e.g., plastic as made from oil), and can be constructed de novo (e.g., diamondoid material) [see 13, pp. 49-52]. The question of the material which is needed to create an artifact results in perceiving artifacts mainly through the prism of the use of natural resources or seeing them as difficult to recycle waste, which pollutes the environment. Such an approach is focused on the fact that artifact is produced at the expense on some natural being. Without a doubt, it cannot be denied that to produce artifacts we need to use some (more or less) natural materials. However, in nature, everything seems to be at the expense of other beings (wolves eating sheep, sheep eating grass, etc.). Do we see only this dependence when we think about those beings? Rather no. If we did, nature would be for us nothing more than a Manichaean sphere of cruelty and darkness. Likewise, if we perceive artifacts only as something that requires using natural resources, we cannot have a positive attitude toward them, and this translates to specific manners of dealings with them (often undesirable from the point of view of ecology).

By the same token, positive attitude towards artifacts is disabled by the belief that artifacts, in contrast to natural beings, are replicable and replaceable because we can always produce another artifact. Such a belief is often expressed in the debate about ecological restoration. Some environmental thinkers are reluctant about it, because they believe it is a false impression that we can restore beings destroyed by humans. Critiques of ecological restoration emphasized that newly planted trees will never replace the concrete trees, which ceased to exist as a result of human activity [see 24, p. 72]. Not denying this claim, I believe that environmental philosophy exhibit unjust disregard for artifacts, because even though they are (mass) produced every artifact is always a particular individual, and as such is a unique entity, which cannot be replaced.

\section{Purchase and Sale}

Dismissing image of artifacts as replaceable has a significant meaning in the analysis of ethical dilemmas related to their purchase and sale. For example, in the case of sale of artifacts, I will, for example, try to answer whether the fact that it consists in selling new things justifies all sale 
practices (how to asses a situation which leads to the purchase of several exemplars of the same artifact that do not have even a chance to be used). Analyzing ethical aspects of the purchase of new goods, I will consider if we have any liabilities to things we already own. This issue will be important to resolve the question what actually justifies purchase of a new thing, resignation from repairing the old one, etc. consider increasingly emerging problem of producing things which have factory-provided short term of performance (which broke just after the expiration of the guarantee), and their repair is more expensive than buying a new product [see 43].

Recognition of artifacts as moral patients will also encourage a critique of consumerism as not related to real needs purchase of new things, which are not perceived as particular individuals, but as signs of wealth, keeping up with fashion and so on. I will refer to the slogan introduced by deep ecology that consumption by improving the standard of life, deteriorates its quality [see 35, $\mathrm{p}$. 222] and show that consumerism does not allow us to create bonds with things we possess. At the same time, my analysis will distance itself from minimalistic attitude, which calls for reducing the number of things we have, because they are seen only as a threat to human freedom. I will argue that such an approach should be replaced by the pursuit to create a positive attitude to things we own (having a sense of connection with them), which should more effectively support long-term and prudent using of artifacts, and in result counter the threat of consumerism.

\section{Post-use Period}

Another important field of ethics of things should be issues related to the period when a usable thing ceases to be able to perform its default function. They can be discussed with reference to the ontology of trash [see 26], which focuses on the transformation of things in the so-called utility and waste. Ethics of things should concentrate on situations, which enable things to fulfill their potential after the standard period of use. These will be basically two phenomena. First one will be recycling, that is a process of converting waste materials into objects, which can be reused for the original purpose (glass bottles) or other goals (making notebooks from wastepaper). The second phenomenon will be a creative reuse, referred to also as repurposing. It consists in restoring things their functionality (restored furniture) or giving them a new form (e.g. making poufs or garden pots out of used tires). I will present these phenomena as something that create opportunities for things to complete the realization of their potential and identity and not only as something that enables people to limit the use of natural resources and reduce production of waste.

\section{Threats}

Including artifacts in the scope of moral considerability requires us to examining negative issues related to the existence of certain artifacts. For example, it should be considered what we should do with objects which standard function is killing (e.g., atomic bombs) or which pollute the air (e.g., old, inefficient cars). It seems we can adopt an analogical strategy as environmental philosophy, which argued that when some being (e.g., virus) is a direct threat to the existence of another being or when it generates only harms to others, they should be eliminated or at least neutralized. By the same token, usable things which are dangerous to people, nature, and other things should be destroyed or, as far as possible, recycled or upcycled.

\section{Conclusion}

This presentation of the possibility of extending moral obligations toward usable things is only a sketch of the problem, which requires further analysis and development. The aim of it was to draw attention to possible, an alternative approach to artifacts. Many environmental thinkers perceive artifacts only as a threat to the environment and therefore postulates limiting their consumption. Meanwhile, as I have argued, it is worth trying to engage positively with things and recognize them as concrete individuals and as such worth ethical concern, what should also result in the reduction 
of consumerism and the production of waste. Such an approach does not intend to undermine other perspectives, but to supplement them. I believe that we start to understand eco-sphere in its original meaning as a household (gr. oikos), only if we take into considerations artifacts as its elements.

\section{References}

1. Attfield, R. Beyond Anthropocentrism, In A. O'Hear (ed.), Philosophy and the Environment, Cambridge 2011.

2. Baker, L.R. The Ontology of Artifacts, Philosophical Explorations, 7(2), 2004.

3. Baker, L.R. The Metaphysics of Everyday Life, Cambridge: Cambridge UP, 2009.

4. Bennett, J. Vibrant Matter: A Political Ecology of Things, Durham - London: Duke University Press, 2010.

5. Benso, S. The Face of Things: A Different Side of Ethics, New York: SUNY, 2000.

6. Bińczyk, E. Posthumanist Tendencies in Science and Technology Studies, Political Dialogues.

Journal of Biopolitics and Contemporary Politcal Theories, 15, 2013.

7. Blok, V. Heidegger's Ontology of Work, Heidegger Studies, 31, 2015.

8. Braidotti, R. The Posthuman, Malden: Polity, 2013.

9. Devall, B. Simple in Means, Rich in Ends. Practicing Deep Ecology, Salt Lake City, 1988.

10. Goodpaster, K. On Being Morally Considerable, Journal of Philosophy, 75 (6), 1978,

11. Goodpaster, K. On Stopping at Everything: A Reply to W. M. Hunt, Environmental Ethics, 3(3), 1980.

12. Gunkel, D. A Vindication of the Rights of Machines, Philosophy \& Technology, 27 (1), 2012.

13. Hale, B. Technology, the Environment and the Moral Considerability of Artefacts, In J.K.B.

Olsen, E. Selinegr \& S. Riis (eds.), New Waves in Philosophy of Technology, New York: Palgrave Macmillan, 2009.

14. Houkes, W. \& Vermaas P.E. Actions versus Functions: A Plea For an Alternative Metaphysics of Artifacts, Monist, 87, 2004.

15. Houkes, W. \& Vermaas P.E. Produced to Use: Combining Two Key Intuitions on the Nature of Artefacts, Techne, 13 (2), 2009.

16. Houkes, W. \& Vermaas P.E. Contemporary Engineering and the Metaphysics of Artefacts: Beyond the Artisan Model, The Monist, 92 (3), 2009.

17. Hullinger, J. Ikea Wants You To Stop Throwing Away Your Ikea Furniture, [online:] http://www.fastcompany.com/3055971/most-creative-people/ikea-wants-you-to-stop-throwingaway-your-ikea-furniture, 2015.

18. Hunt, W. M. Are Mere Things Morally Considerable? Environmental Ethics, 2(3), 1980.

19. Ihde, D. Expanding Hermeneutics, Evanston: Fordham UP, 1998.

20. Ihde, D. Postphenomenology, Evanston: Fordham UP, 1993.

21. Introna, L. Ethics and Speaking of Things, Theory, Culture \& Society, 3, 2009.

22. Katayama, E. Aristotle on Artifacts: a Metaphysical Puzzle, Albany: SUNY, 1999.

23. Katz, E. Understanding Moral Limits in the Duality of Artifacts and Nature: A Reply to Critics, Ethics \& the Environment, 1, 2002.

24. Katz, E. Further Adventures in the Case Against Restoration, Environmental Ethics, 1, 2012.

25. Katz, E. Artefacts and Functions: A Note on the Value of Nature, Environmental Values, 2, 1993.

26. Kennedy, G. An Ontology of Trash. The Disposable and Its Problematic Nature, Albany: SUNY, 2012.

27. Kiepas A. Człowiek wobec dylematów filozofii techniki, Katowice: Wyd. UŚ, 2000.

28. Kim, J. Phenomenogy of Digital-Being, Human Studies, no. 24, 2001.

29. King, R. 2002. Environmental Ethics and the Built Environment, Environmental Ethics, 22(2), 2002, pp. 115-131.

30. Kotarbinski, T. Fazy rozwojowe konkretyzmu, Studia Filozoficzne, 1, 1958, pp. 228-236.

31. Kotarbinski, T. Zasadnicze myśli pansomatyzmu, Przeglad Filozoficzny, 33, 1934, pp. 283-294. 
32. Kozłowski, J. O reizmie somatycznym Tadeusza Kotarbinskiego, Studia Humanistyczne Akademii Górniczo-Hutniczej. Prace Filozoficzne, 27, 1985, pp. 28-39.

33. Lee, K. The Natural and the Artefactual. The Implications of Deep Science and Deep Technology for Environmental Phislosophy, Lanham - Boulder - New York - Oxford: Lexington Books, 1999.

34. Lizut, R. A. Technika a wartości. Spór o aksjologicza neutralność artefaktów, Lublin: Academicon, 2014.

35. Maskit, J. Deep Ecology and Desire: On Naess and the Problem of Consumption, In E. Katz, A. Light, D. Rothenberg (eds.), Beneath the Surface. Critical Essays in the Philosophy of Deep Ecology, Cambridge - London: MIT Press, 2000.

36. Morito, B. Intrinsic Value: A Modern Albatross for the Ecological Approach, Environmental Values, 12: 2003, pp. 317-336.

37. Naess, A. The Deep Ecology Movement, G. Sessions (ed.), In Deep Ecology for the TwentyFirst Century, Boston - London, 1995.

38. Newman, L. \& Dale, A. Celebrating the Mundane: Nature and the Built Environment, Environmental Values, 22: 2013, pp. 401-413.

39. Norton, B. Convergence, Noninstrumental Value and the Semantics of 'Love': Comment on McShane, Environmental Values, 17, 2008, pp. 5-14.

40. Ouderkirk, W. Katz's Problematic Dualism and its "Seismic" Effects on His Theory, Ethics \& the Environment, 7(1), 2002, pp. 124-137.

41. Piątek, Z. Aspekty antropocentryzmu, Kraków: Wyd. UJ, 1988.

42. Piątek, Z. Etyka środowiskowa. Nowe spojrzenie na miejsce człowieka w przyrodzie, Kraków: Księgarnia Akademicka, 1998.

43. Przybysz, A. Raport: czas użytkowania lodówek i telewizorów coraz krótszy. Wina producentów? Gazeta Wyborcza, 15.04.2015.

44. Thompson, I. Landscape and Environmental Ethics, In P. Howard, I. Thompson, \& E. Waterton (eds.), The Routledge Companion to Landscape Studies, London and New York: Routledge, 2013. 45. Tymieniecka-Suchanek, J. (ed.). 2014 Człowiek $w$ relacji do zwierząt, roślin $i$ maszyn $w$ kulturze. Od humanizmu do posthumanizmu, t. 1-2, Katowice: Wyd. UŚ, 2014.

46. Verbeek, P.-P. What Things Do. Philosophical Reflections on Technology, Agency, and Design, University Park: Penn State UP, 2005.

47. Vermaas P., Kroes P., \& Franssen M. A Philosophy of Technology: From Technical Artefacts to Sociotechnical Systems, Morgan \& Claypool Publishers, 2011.

48. Vogel, S. Environmental Philosophy after the End of Nature, Environmental Ethics, 24(1), 2002. 49. Vogel, S. The Nature of Artfiacts, Environmental Ethics, 25(2), 2003.

50. Vogel, S. Thinking like a Mall, Cambridge: MIT Press, 2015. 